\title{
Effect of Ultrasonic Pretreatment of Sewage Sludge on the Performance of Bioelectrochemical Anaerobic Digester
}

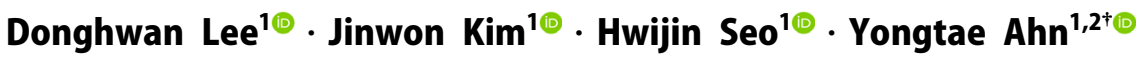 \\ ${ }^{1}$ Department of Energy Engineering, Gyeongsang National University, Republic of Korea \\ ${ }^{2}$ Future Convergence Technology Research Institute, Gyeongsang National University, Republic of Korea
}

(Received January 5, 2022; Revised January 19, 2022; Accepted January 19, 2022)

Objectives: This study examined the effect of ultrasonic pretreatment on primary sewage sludge (raw sludge) solubilization and its subsequent microbial electrolysis cells (MECs) operation performance.

Methods : To compare the effect of ultrasound on raw sludge solubilization, ultrasonic pretreatment was conducted at $1 \sim 4 \mathrm{~W} / \mathrm{mL}$ energy density for $5 \sim 30 \mathrm{~min}$. In MECs operation, raw sludge was used as a control group, and ultrasound pretreated sludge was used as an experimental group. For comparing MECs performance, biogas production, and organic matter removal were analyzed.

Results and Discussion: The optimal experimental condition for ultrasonic pretreatment were 30 min of sonication time at $3 \mathrm{~W} / \mathrm{mL}$. In methane production, MEC with ultrasound pretreatment (MEC $3 \mathrm{~W}$ ) produced 243 $\mathrm{mL} / \mathrm{L}$ more methane than that of unpretreated MEC (MEC) by $4,970 \mathrm{~mL} / \mathrm{L}$ at 1,3 cycles. In the modified Gompertz model analysis, the lag phase of MEC $3 \mathrm{~W}$ was 0.46 days, which was 0.12 days longer than MEC. The maximum methane production rate of MEC $3 \mathrm{~W}$ by $938.5 \mathrm{~mL} / \mathrm{L} /$ day was also higher than MEC. MEC $3 \mathrm{~W}$ showed a $1.8 \%$ higher TS removal rate, $2.4 \%$ VS removal rate than MEC. COD removal rate also improved by $2.0 \%$ when ultrasound pretreatment was applied. The methane yield of MEC with ultrasound pretreatment $\left(377.4 \mathrm{~mL} / \mathrm{g} \mathrm{VS}_{\text {in }}\right.$.) was $0.4 \%$ higher than that of MEC without pretreatment.

Conclusion: Ultrasonic pretreatment of sewage sludge improved the methane production and organic removal in microbial electrolysis cells. It is necessary to find the optimal operating conditions to obtain the maximize the performance.

Keywords : Microbial electrolysis cell, Ultrasound pretreatment, Sewage sludge, Bio gas 


\title{
연구논문
}

\section{생물전기화학 혐기 소화조를 이용한 초음파 전처리가 적용된 하수 슬러지의 소화성능 평가}

\author{
이동환 $^{1 \oplus} \cdot$ 김진원 $^{1 \oplus} \cdot$ 서휘진 $^{1 \odot} \cdot$ 안용태 $^{1,2^{+} \oplus}$ \\ ${ }^{1}$ 경상국립대학교 에너지공학과 \\ 2경상국립대학교 미래융복합기술연구소
}

목적 : 본 연구는 초음파 강도 및 시간에 따른 1 차 하수슬러지(생슬러지)의 가용화도에 대한 비교 후 회분식 실험 을 통해 미생물전기분해전지(Microbial electrolysis cell, MEC)의 운전성능을 조사하였다.

방법: 초음파 처리에 따른 생슬러지의 가용화도에 대해 비교하기 위하여 $1 \sim 4 \mathrm{~W} / \mathrm{mL}$ energy density로 5 30분간 주 사하였다. MEC 운전에서 대조군으로 전처리를 수행하지 않은 생슬러지와 실험군으로 $3 \mathrm{~W} / \mathrm{mL}$ energy density로 30 분간 초음파 전처리된 생슬러지를 사용하였다. MEC 운전성능을 비교하기 위하여 바이오가스 생산량, 유기물제 거 등을 분석하였다.

결과 및 토의 : 초음파 전처리에 따른 슬러지 가용화도 실험결과, 에너지효율을 고려할 때 $3 \mathrm{~W} / \mathrm{mL}, 30$ 분 조건이 최 적인 것으로 나타났다. 메탄 생산에서 $\mathrm{MEC} 3 \mathrm{~W}$ (초음파 전처리를 수행한 $\mathrm{MEC}$ )가 1,3 사이클에서 평균 4,790 $\mathrm{mL} / \mathrm{L}$ 로 MEC (전처리를 수행하지 않은 MEC) $243 \mathrm{~mL} / \mathrm{L}$ 더 많이 생산되었다. Modified Gompertz model을 통한 모 델분석에서 lag phase는 MEC $3 \mathrm{~W}$ 가 0.46 일로 $\mathrm{MEC}$ 에 비해 0.12 일 길었으나 최대 메탄 생산속도가 $938 \mathrm{~mL} / \mathrm{L} / \mathrm{day}$ 로 더 높았다. 유기물 제거율은 $\mathrm{MEC} 3 \mathrm{~W}$ 가 대조군에 비해 $\mathrm{TS}$ 는 $1.8 \%, \mathrm{VS}$ 는 $2.4 \%, \mathrm{COD}$ 는 $2.0 \%$ 각각 더 높았다. 메탄 수율은 $377.4 \mathrm{~mL} / \mathrm{g} \mathrm{VS}$ in으로 초음파 전처리를 수행하지 않은 $\mathrm{MEC}$ 에 비해 $0.4 \%$ 높았다.

결론 : $\mathrm{MEC}$ 에서 초음파 전처리한 슬러지를 기질로 사용하여 메탄가스 발생량과 유기물 제거율의 증가가 가능하였 다. 향후 전처리가 적용된 하수슬러지를 기질로 하여 최고의 운전성능을 보여주기 위한 최적의 전처리 방법을 찾 는 후속 연구가 필요하다.

주제어 : 미생물전기분해전지, 초음파 전처리, 하수 슬러지, 바이오가스

\section{1. 서 론}

인구 증가에 따른 전국의 하수슬러지 발생량은 2008년 7,719 ton/day에서 2017년엔 11,491 ton/day로 약 33\% 증가하 고 있다. ${ }^{1)}$ 슬러지 및 폐기물의 해양 투기가 2012년부터 런던 협약에 따라 금지되어 하수 슬러지의 적절한 처리법에 관해 논의되게 되었고 그 중 하나가 혐기성 소화이다. ${ }^{2)}$ 혐기성 소 화는 고분자를 저분자로 분해시키는 가수분해(Hydrolysis), 저분자를 단사슬 유기산(Short chain fatty acid; SCFA)으로 변 환시키는 산생성 단계(Acidogenesis), $\mathrm{C} 3-\mathrm{C} 5$ 의 $\mathrm{SCFA}$ 를 $\mathrm{C} 2$ 인 아세트산으로 전환시키는 아세트산 생성단계(Acetogenesis), 그리고 생성된 아세트산을 메탄으로 전환시키는 메탄생성단 계(Methanogenesis)가 있다. ${ }^{3)}$ 혐기성 소화는 메탄가스 형태로 에너지를 생산하면서 슬러지 부피를 줄일 수 있고, 소화가 끝 난 슬러지를 비료로 사용할 수 있는 친환경적인 장점이 있으
나, 느린 가수분해와 메탄생성단계로 인한 긴 소화시간, 가수 분해와 산생성단계의 진행 속도 불균형에 의한 $\mathrm{pH}$ 불균형, 소화에 사용되는 기질에 따라 변동이 큰 성능과 낮은 소화효 율 등의 단점이 있다.) 앞서 설명한 혐기성 소화의 단점을 극 복하고 메탄가스의 조성을 높이기 위해 미생물전기분해전지 (Microbial electrolysis cell; $\mathrm{MEC}$ )가 개발되었다. ${ }^{5}$ 미생물전기 분해전지는 생물전기화학기술(Bioelectrochemical technology) 중 하나로 소화조 내에 산화전극과 환원전극이 삽입되어 있고 열역학적 장벽을 넘어설 수 있을 정도의 미량의 전압 $(0.2-1.23 \mathrm{~V})$ 을 인가하면 전극 표면의 전기활성 박테리아 (Electrochemically active bacteria)의 전기화학적 산화환원 반 응을 통해 혐기소화 성능을 향상시킬 수 있는 것으로 보고되었 다. ${ }^{67)} \mathrm{MEC}$ 의 메탄 생산과정은 전극으로부터 직접적으로 전 자를 전달받아 메탄을 생산하는 방식(Electromethanogenesis, 식 (1))과 수소 또는 acetate, formate 등과 같은 물질이 이산화 
탄소와 결합하여 메탄을 생산하는 방식(Mediated or indirect electromethanogenesis, 식 (2))이 있는 것으로 보고되고 있다. ${ }^{8)}$ 선행연구에서 생슬러지를 기질로 사용한 유효부피 $2 \mathrm{~L}$ 의 $\mathrm{MEC}$ 를 운전하였을 때 $0.3 \mathrm{~V}$ 를 인가한 $\mathrm{MEC}$ 의 메탄 수율이 $170.2 \mathrm{~L} / \mathrm{kg}$-VSS로 기존 $\mathrm{AD}$ 보다 $81.6 \%$ 증가하였다. ${ }^{9)} \mathrm{Zhao}$ et al.에서 활성슬러지(Waste activated sludge; WAS)를 기질로 $0.6 \mathrm{~V}$ 를 인가하여 $\mathrm{MEC}$ 를 운전하였을 때 메탄 생산량은 혐기 소화에 비해 $30.2 \%$ 증가하였고, $\mathrm{VS}$ 는 $24.5 \%$ 더 많이 제거하 였다. ${ }^{10)}$

Direct electromethanogenesis:

$$
\mathrm{CO}_{2}+8 \mathrm{H}^{+}+8 e^{-} \rightarrow \mathrm{CH}_{4}+2 \mathrm{H}_{2} \mathrm{O}
$$

Indirect electromethanogenesis:

$$
\mathrm{CO}_{2}+4 \mathrm{H}_{2} \rightarrow \mathrm{CH}_{4}+2 \mathrm{H}_{2} \mathrm{O}
$$

슬러지 내 세포 외 고분자 물질(Extracellular polymeric substances) 등과 같은 물질들은 혐기성 소화와 미생물전기분 해전지 내의 미생물에 의해 쉽게 분해되지 않아 가수분해 속 도가 느려진다는 단점이 있다. ${ }^{11)}$ 가수분해 단계를 강제로 단 축시키고 메탄 생산을 향상시키는 방법으로 하수슬러지에 전 처리를 적용하는 방법이 보고되고 있다. ${ }^{12)}$ 종류는 물리적, 열 적, 화학적(산, 염기), 생물학적, 그리고 두 가지 이상의 전처 리를 합친 병합 전처리가 있다. ${ }^{13)}$ 전처리의 목적은 EPS를 녹 이고 세포벽을 강제로 파괴시켜 내부의 유기산과 SCOD 등을 방출시켜 가용화를 통해 가수분해 시간을 강제로 단축시키며 동시에 바이오가스 생산량도 증가시키는 것이다. ${ }^{14)}$ 다양한 전 처리 방법 중 널리 사용되는 전처리 중 하나로 초음파 전처리 가 있다. 초음파 전처리는 물리적 전처리 방법 중 하나로 초음 파에 의한 마이크로 버블이 미세 공동(microcavitation) 현상 에 의해 슬러지 플록을 파괴시키며 가용화를 진행시키는 것으 로 보고되었다. ${ }^{15)}$ 다른 선행연구에서 $30 \mathrm{~g}$ 의 하수슬러지를 $150 \mathrm{~W}$ 조건으로 45 분 동안 초음파 전처리를 수행한 하수슬러
지를 이용하여 혐기소화를 진행하였을 때 메탄 수율은 172 $\mathrm{mL} / \mathrm{g} \mathrm{VS}_{\mathrm{in}}$ 으로 전처리를 하지 않았던 조건보다 $96 \%$ 증가된 수율을 보여주었다. ${ }^{16)}$ 또한 WAS에 $0.5 \mathrm{~W} / \mathrm{mL}$ energy density 로 10 분간 초음파 전처리 후 $\mathrm{NaOH}$ 를 이용하여 $\mathrm{pH} 10$ 까지 알칼리 전처리를 수행한 뒤 $0.8 \mathrm{~V}$ 를 인가하여 운전한 $\mathrm{MEC}$ 에 서 메탄 생산량은 $808 \mathrm{~mL}$ 로 전처리를 수행하지 않은 혐기소 화보다 $97 \%, \mathrm{VSS}$ 제거율은 $657 \%$, TCOD 제거율은 $166 \%$ 증 가한 경향을 보여주어 기질에 전처리를 수행하여 혐기소화 또는 $\mathrm{MEC}$ 를 운전하였을 때 성능이 향상되는 것으로 보고되 었다. ${ }^{17)}$ 난분해성인 생슬러지를 초음파 전처리 혐기소화 관련 논문은 여러 차례 보고되었으나 $\mathrm{MEC}$ 를 운전하여 성능을 비 교한 논문은 많이 보고되지 않았다.

따라서 본 연구는 초음파 전처리를 생슬러지에 적용하였을 때 가용화에 대해 알아보고 뒤이어 $\mathrm{MEC}$ 회분실험을 통해 운 전성능에 대해 알아보았다. $1 \sim 4 \mathrm{~W} / \mathrm{mL}$ 가용화도 실험을 통해 실험군의 운전 조건을 잡고 이후 회분실험을 통해 바이오가스 발생량, 유기물 제거율 등에 대해 알아보았다.

\section{2. 실험 재료 및 방법}

\section{1. 슬러지 및 초음파 전처리 실험}

운전에 사용된 $\mathrm{MEC}$ 슬러지는 다른 $\mathrm{MEC}$ 반응기의 슬러지 를 사용하였고, 전처리에 사용된 기질과 사전실험에 사용된 1 차 하수 슬러지는 $\mathrm{J}$ 시 하수처리장에서 채취하여 $850 \mu \mathrm{m}$ 체 로 거른 후 $4^{\circ} \mathrm{C}$ 이하에서 24 시간 이상 안정화시킨 후 사용하 였다(Table 1).

$\mathrm{MEC}$ 운전에 앞서 초음파 전처리 가용화도를 알아보기 위 한 사전실험을 수행하였다. Q500 $(20 \mathrm{kHz}$ frequency, Qsonica SONICATORS)에 장착된 $19 \mathrm{~mm}$ 팁을 바닥에서 $2 \mathrm{~cm}$ 띄워 $1,2,3,4 \mathrm{~W} / \mathrm{mL}$ energy density로 $5,10,20,30$ 분 동안 온도 영향을 최소화하기 위해 iced bath에서 진행하였다.

\begin{tabular}{|c|c|c|c|c|c|}
\hline & MEC seed & Sludge & $3 \mathrm{~W} / \mathrm{mL}^{1}$ & $\mathrm{MEC}_{\mathrm{in}}{ }^{2}$ & MEC $3 W_{i n}{ }^{3}$ \\
\hline TS (g/L) & $15.0 \pm 2.0$ & $30.7 \pm 0.7$ & $30.6 \pm 0.3$ & $23.2 \pm 6.8$ & $19.1 \pm 11.6$ \\
\hline VS (g/L) & $10.1 \pm 1.6$ & $24.8 \pm 1.1$ & $25.3 \pm 0.1$ & $17.2 \pm 5.6$ & $14.3 \pm 9.0$ \\
\hline TCOD $(\mathrm{g} / \mathrm{L})$ & $13.8 \pm 1.8$ & $33.1 \pm 7.6$ & $34.5 \pm 1.8$ & $24.1 \pm 7.2$ & $23.6 \pm 14.9$ \\
\hline $\mathrm{SCOD}(\mathrm{g} / \mathrm{L})$ & $0.9 \pm 0.2$ & $3.0 \pm 1.2$ & $6.7 \pm 1.2$ & $1.1 \pm 0.8$ & $2.8 \pm 2.5$ \\
\hline $\mathrm{pH}$ & $7.7 \pm 0.1$ & $5.6 \pm 0.1$ & $5.5 \pm 0.0$ & $7.5 \pm 0.5$ & $7.5 \pm 0.5$ \\
\hline $\begin{array}{c}\text { Alkalinity } \\
\left(\mathrm{mg} / \mathrm{L} \text { as } \mathrm{CaCO}_{3}\right)\end{array}$ & $4,368 \pm 455$ & $665 \pm 92$ & $812 \pm 98$ & $2,813 \pm 734$ & $2,965 \pm 502$ \\
\hline $\mathrm{DS}^{4}(\%)$ & - & - & $16.3 \pm 5.2$ & - & - \\
\hline
\end{tabular}

Table 1. Characteristics of sludge samples.

\footnotetext{
${ }^{1} 3 \mathrm{~W} / \mathrm{mL}$ energy density ultrasound pretreated sludge.

${ }^{2} 1: 1(\mathrm{v} / \mathrm{v})$ ratio mixed with unpreated sludge and MEC seed sludge.

${ }^{3} 1: 1(\mathrm{v} / \mathrm{v})$ ratio mixed with $3 \mathrm{~W} / \mathrm{mL}$ enrgy density ultrsound pretreated sludge and MEC seed sludge.

${ }^{4}$ Degree of solubilization.
} 


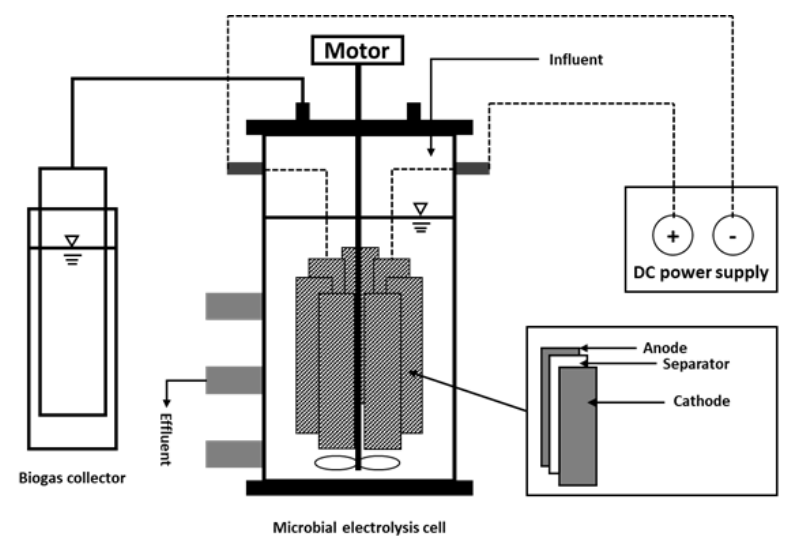

Fig. 1. Schematic diagram of MECs."

\section{2. 반응기 구성 및 운전}

$\mathrm{MEC}$ 회분식 운전에 사용된 유효부피 $1.7 \mathrm{~L}$ 반응기를 Fig. 1 에 나타내었다. 산화전극과 환원전극 모두 흑연섬유직물(Graphite fiber fabric; GFF)의 표면에 전기영동증착법(Electrophoretic deposition; EPD)으로 다중벽 탄소나노튜브(Multi-walled carbon nanotube; MWCNT)와 $\mathrm{Ni}^{+}$로 코팅시켰다. 코팅 후 24.5 $\mathrm{mm} \times 140 \mathrm{~mm}$ 의 크기로 잘라 제작된 틀에 산화전극-부직포환원전극 세트(Separator electrode assembly; SEA)로 7쌍을 삽입하였고 반응기 벽면의 스테인리스 봉을 삽입하여 전압을 인가시켰다. ${ }^{6}$ 중온소화조건을 유지하기 위해 열선과 단열재 로 감쌌다. 소화를 통해 발생되는 바이오가스를 포집하기 위 한 가스 포집기는 아크릴로 제작하였으며 발생된 가스가 용해 되지 않도록 염화나트륨 $(\mathrm{NaCl})$ 을 과포화시킨 후 황산을 이용 하여 $\mathrm{pH} 2$ 이하가 되도록 제작하였다. ${ }^{18)}$

$\mathrm{MEC}$ 운전은 다른 반응기의 $\mathrm{MEC}$ 슬러지와 기질을 2 개의 반응기에 각각 $1: 1(\mathrm{v} / \mathrm{v} \%)$ 의 비율로 혼합하여 주입하였다. 운 전에 사용된 기질은 대조군인 생슬러지와 사전실험을 통해 운전 조건을 결정한 $3 \mathrm{~W} / \mathrm{mL}$ energy density로 30 분간 초음파 처리한 생슬러지를 사용하였다. 모든 반응기는 전압공급장치 (OPM93 4CH, ODA Technologies Co. Ltd.)를 이용하여 0.3 $\mathrm{V}$ 의 전압을 인가하였고, $10 \Omega$ 의 외부저항을 연결하였다. 질 소가스를 이용하여 각각 10 분씩 퍼징하여 반응기 내부를 혐 기성 상태로 유지시켰고, $100 \mathrm{rpm}$ 의 교반속도로 반응기 내부 를 교반시켰다.

\section{3. 분석 방법}

$\mathrm{MEC}$ 의 운전조건을 정하기 위해 초음파 전처리 실험에서 계산에 사용된 가용화도(\%)는 아래의 식 (3)을 이용해 계산하 였다. ${ }^{19)}$

Degree of solubilization:

$$
\frac{T C O D_{\text {raw }}-S C O D_{\text {pretreatment }}}{T C O D_{\text {raw }}-S C O D_{\text {raw }}} \times 100
$$

$T C O D_{\text {raw }}$ 와 $S C O D_{\text {raw }}$ 는 각각 전처리 전 슬러지의 TCOD 와 $\mathrm{SCOD}$ 이며 $S C O D_{\text {pretreatment }}$ 는 전처리 후 슬러지의 $\mathrm{SCOD}$ 이다.

발생된 바이오가스의 조성은 24 시간 마다 열전도도 검출기 (Thermal conductivity detector; TCD)와 Porapak Q mesh (80/100) column이 장착된 Gas Chromatograph (Series 580, GowMac Instrument Co.)를 사용하였다. Column $50^{\circ} \mathrm{C}$, detector $80^{\circ} \mathrm{C}$, injector $90^{\circ} \mathrm{C}$ 조건에서 캐리어 가스로 초고순도 질소를 $30 \mathrm{~mL} / \mathrm{min}$ 의 유량으로 측정하였다. 아래의 식 (4)를 이용해 측정된 바이오가스량을 표준상태(STP, Standard temperature and pressure)로 환산하였다. ${ }^{20)}$

$$
V_{C H_{4}}(S T P L)=V_{C H_{4}}(\text { at } T) \times \frac{273}{273+T} \times \frac{760-W}{760}
$$

$T$ 는 반응조의 온도 $\left({ }^{\circ} \mathrm{C}\right), W$ 는 $T$ 에 따른 포화 수증기압 $(\mathrm{mmHg})$ 을 나타낸다. 유입수와 유출수의 $\mathrm{pH}$, Alkalinity는 $\mathrm{pH}$ meter (Orion Star A Series, Thermo Fisher Scientific Ltd. Korea)로 분석하였으며 TS, VS, $\mathrm{COD}_{\mathrm{Cr}}$ 는 Standard Methods 에 따라 분석하였다. ${ }^{21}$

최대 메탄 생산율 $(\mathrm{Rm})$, 잠재 메탄 생산량( $(\mathrm{P})$, lag phase $(\lambda)$ 를 알아보기 위해 modified Gompertz model 분석을 아래의 식 (5)를 통해 진행하였다. ${ }^{22)}$

$$
P(t)=P \exp \left\{-\exp \left[\frac{2.718 \times R_{m}}{P} \times(\lambda-t)+1\right]\right\}
$$

$P(t)$ 는 누적 메탄 생산량 $(\mathrm{mL}), P$ 는 잠재 메탄 생산량 $(\mathrm{mL})$, $R_{m}$ 은 최대 메탄 생산율( $\left.\mathrm{mL} / \mathrm{day}\right), \lambda$ 는 lag phase (day)이다.

\section{3. 결과 및 분석}

\section{1. 생슬러지의 초음파 전처리 가용화도 실험}

$\mathrm{MEC}$ 운전에 앞서 최적의 초음파 강도 및 주사시간을 정하

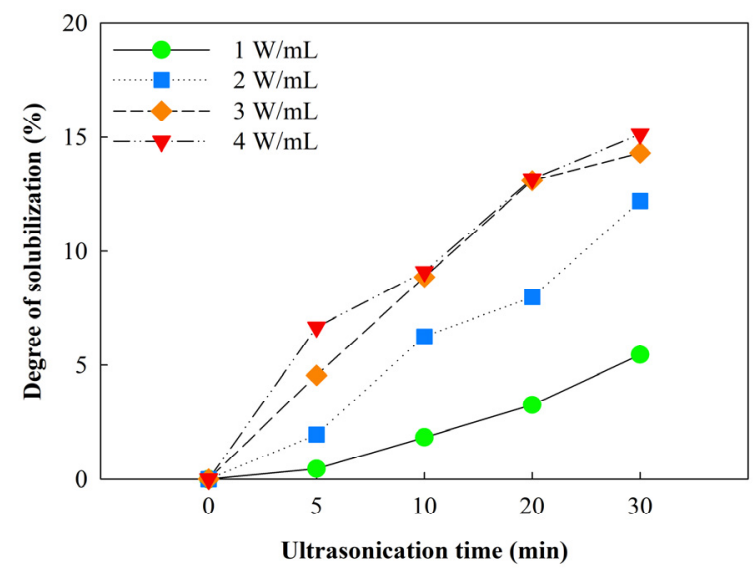

Fig. 2. Degree of solubilization of ultrasound pretreatment at different ultrasonic density. 
기 위해 회분식 실험을 진행 결과를 Fig. 2에 나타내었다. 모든 energy density 조건에서 5 분에서 30 분으로 전처리 시간이 길 어질수록 가용화도가 증가하였다. Energy density 조건도 비 슷한 경향으로 $1 \mathrm{~W} / \mathrm{mL}$ energy density에서 $4 \mathrm{~W} / \mathrm{mL}$ energy density로 강도가 증가할수록 가용화도가 증가하였다. 30 분 처리 시 $1 \mathrm{~W} / \mathrm{mL}$ energy density 조건에서의 가용화도는 $5.5 \%$ 였고, $2 \mathrm{~W} / \mathrm{mL}$ energy density에서 약 $220 \%$ 증가한 $12.2 \%$ 의 가용화도를 보여주었다. 같은 초음파 처리 시간에서 강도가 높을수록 가용화도 증가폭은 감소하였다. $3 \mathrm{~W} / \mathrm{mL}$ energy density 조건에서 증가폭은 감소하여 $14.3 \%$ 의 가용화 도를 보여주었고, $4 \mathrm{~W} / \mathrm{mL}$ energy density 조건은 훨씬 더 감 소하여 $0.8 \%$ 더 높은 가용화도를 보여주었다. 초음파 전처리 시 발생된 미세공동이 생슬러지 내의 플록(floc)을 파괴시켜 수성상에서의 유기물과 $\mathrm{EPS}$ 의 가용화로 인해 $\mathrm{SCOD}$ 가 증가 된 것으로 생각된다. ${ }^{15)} 3,4 \mathrm{~W} / \mathrm{mL}$ energy density 조건에서 10 30분 동안 초음파 처리 시 가용화도의 변화는 크지 않았 다. 30 분 동안 초음파 처리 시 $3 \mathrm{~W} / \mathrm{mL}$ energy density는 $180,904 \mathrm{~kJ} / \mathrm{kg}$ TS, $4 \mathrm{~W} / \mathrm{mL}$ energy density는 $241,206 \mathrm{~kJ} / \mathrm{kg}$ TS로 $4 \mathrm{~W} / \mathrm{mL}$ energy density 조건이 $60,302 \mathrm{~kJ} / \mathrm{kg}$ TS 더 많이 에너지가 들어갔음에도 가용화도에서 $0.8 \%$ 차이를 보였다. 이는 energy density가 증가할수록 미세공동 기포의 크기가 커 지게 되어 기포 파괴가 충분히 일어나지 않았기 때문으로 판 단된다. ${ }^{23)}$ 따라서 본 실험에서 실험군은 30 분 동안 $3 \mathrm{~W} / \mathrm{mL}$ energy density로 슬러지를 전처리하여 운전하였다.

\section{2. 초음파 전처리로 인한 MEC의 바이오가스 생산 특성}

가용화도 실험을 통해 얻어진 최적 조건에서 $\mathrm{MEC}$ 회분실 험을 통한 가스 발생량에 대해 Fig. 3에 나타내었다. 전처리에 관계없이 모든 반응기의 첫 번째와 세 번째 사이클의 운전 시간은 12 일 이었고, 두 번째 사이클은 9일 이었다. $\mathrm{MEC}$ (초 음파 전처리를 수행하지 않은 $\mathrm{MEC}$ )는 운전 시작 후 1 일째부 터 평균 $690 \mathrm{~mL} / \mathrm{day}$ 로 $\mathrm{MEC} 3 \mathrm{~W}$ (초음파 전처리를 수행한 $\mathrm{MEC}$ )보다 $49 \mathrm{~mL} / \mathrm{day}$ 더 많은 양의 메탄을 생산하기 시작했 다(Fig.3(a)). 두 반응기 모두 각 사이클 별 최고 메탄 생산량 은 첫 번째 사이클은 2 일, 두 번째 사이클은 3 일, 세 번째 사이 클은 2일로 동일하였다. MEC는 두 번째 사이클의 운전 3 일차 에 $857 \mathrm{~mL} / \mathrm{day}$ 로 일일 최고 메탄 생산량을 보여주었다. $\mathrm{MEC}$ $3 \mathrm{~W}$ 도 비슷한 경향으로 운전 3 일차에 $972 \mathrm{~mL} / \mathrm{day}$ 의 일일 최 고 메탄 생산량을 보여주었다. $\mathrm{MEC} 3 \mathrm{~W}$ 의 첫 번째, 세 번째 사이클 평균 누적 메탄 생산량은 $4,970 \mathrm{~mL} / \mathrm{L}$ 로 $\mathrm{MEC}$ 에 비해
$243 \mathrm{~mL} / \mathrm{L}$ 더 많이 생산되었다(Fig.3(b)). 유효부피 $269 \mathrm{~mL}$ 반응기를 이용하여 WAS에 초음파 전처리를 적용하여 $0.5 \mathrm{~V}$ 를 인가하여 운전했던 문헌에서 바이오가스 생산량이 $368 \%$ 증가한 것으로 보고되었다. ${ }^{24)}$ 또한 $100 \mathrm{~L}$ 의 연속식 반응기를 이용하여 2차 슬러지에 초음파 전처리를 하여 혐기 소화시켰 을 때 16 초간 초음파 전처리를 한 조건에서 대조군에 비해 $42 \%$ 바이오가스 생산량이 증가한 것으로 보고되었다. ${ }^{25)}$ 이는 초음파 전처리 시 유기물 가용화를 통한 용해성 유기물 생성 및 방출 때문인 것으로 사료된다. ${ }^{26}$ Modified Gompertz model 을 통한 계산에서 본격적으로 메탄이 생산되기까지 걸리는 시간을 나타내는 lag phase $(\lambda)$ 는 모두 1일 이내로 매우 빠 른 속도로 생산되는 것을 도출해낼 수 있었으나 MEC $3 \mathrm{~W}$ 의 $\lambda$ 값이 평균 0.12 일 길었다. 올리브 찌꺼기(Olive pomace) 를 $450 \mathrm{~W}$ 로 10 분간 초음파 전처리하여 메탄 생산 퍼텐셜 (Biochemical methane potential, BMP) 실험을 통한 연구에서 초음파 전처리 시 $\lambda$ 값이 2 일 길었던 것으로 보고되었다.27) 음식물 쓰레기를 이용한 바이오가스 생산연구에서 $79 \mathrm{~kJ} / \mathrm{g}$ $\mathrm{TS}$ 의 에너지를 주사했던 초음파 전처리 조건에서 $\lambda$ 값이 31.1 일 길었다. ${ }^{28)}$ 이는 초기에 초음파 전처리를 통해 슬러지 가용화를 강제시켰으나 이를 통해 방출된 초기 물질들을 메 탄 생성균이 섭취하기 어렵기 때문으로 사료된다. ${ }^{29}$ 최대 메 탄 생산율인 $R_{m}$ 은 $\mathrm{MEC} 3 \mathrm{~W}$ 가 $938.5 \mathrm{~mL} / \mathrm{L} / \mathrm{day}$ 로 평균 120 $\mathrm{mL} / \mathrm{L} / \mathrm{day}$ 높았다. 이는 $\mathrm{MEC}$ 의 생물전기화학적 산화화원 반 응으로 빠르게 유기물 및 유기산을 제거하여 $\lambda$ 를 1 일 이내로 감소시킬 수 있었고, 초음파 전처리로 인한 가용화를 통해 메 탄 생성균이 섭취하기 쉬운 저분자 물질로 분해되고 $\mathrm{SCOD}$ 가 증가되며 $R_{m}$ 이 $\mathrm{MEC}$ 에 비해 높았던 것으로 사료된다. ${ }^{30,31)}$

\section{3. 초음파 전처리로 인한 MEC 운전에서 유기물 제거 및 메탄 수율변화}

초음파 전처리가 MEC 운전에서 유기물 제거와 메탄 수율 에 미치는 영향을 Fig.4에 표시하였다. MEC $3 \mathrm{~W}$ 의 TS와 VS 제거율은 $\mathrm{MEC}$ 에 비해 각각 $1.8,2.4 \%$ 높았다. $\mathrm{COD}$ 제거율 역시 $\mathrm{MEC} 3 \mathrm{~W}$ 가 $39.6 \%$ 로 $2.0 \%$ 높은 제거율을 보여주었다. 음식물 쓰레기를 혐기 발효하여 수소 생산 시 단일 전처리(열, 초음파, 산, 염기) 중 가장 높은 $\mathrm{COD}$ 제거율을 보였다. ${ }^{27}$ 또한 tWAS (thickened WAS)를 기질로 혐기 소화한 연구에서 전처 리를 수행하지 않은 혐기 소화조보다 높은 유기물 제거율과 바이오가스 생산량을 가진 것으로 보고되었다. ${ }^{32}$ 문헌과 실험 결과가 일치하는 이유는 초음파 전처리 시 미세공동과 함께

Table 2. Modified Gompertz model parameters.

\begin{tabular}{ccccc} 
& $P(\mathrm{~mL} / \mathrm{L})$ & $R_{m}(\mathrm{~mL} / \mathrm{L} / \mathrm{day})$ & $\lambda($ day $)$ & $\mathrm{DCP}^{1}\left(\mathrm{~mL} / \mathrm{L} / \mathrm{day}^{2}\right)$ \\
MEC & $4,865 \pm 174$ & $819 \pm 115$ & $0.34 \pm 0.2$ & $396 \pm 4$ \\
\hline MEC 3W & $4,808 \pm 341$ & $939 \pm 134$ & $0.46 \pm 0.1$ & $398 \pm 28$ \\
\hline
\end{tabular}

${ }^{1}$ Average daily methane production. 


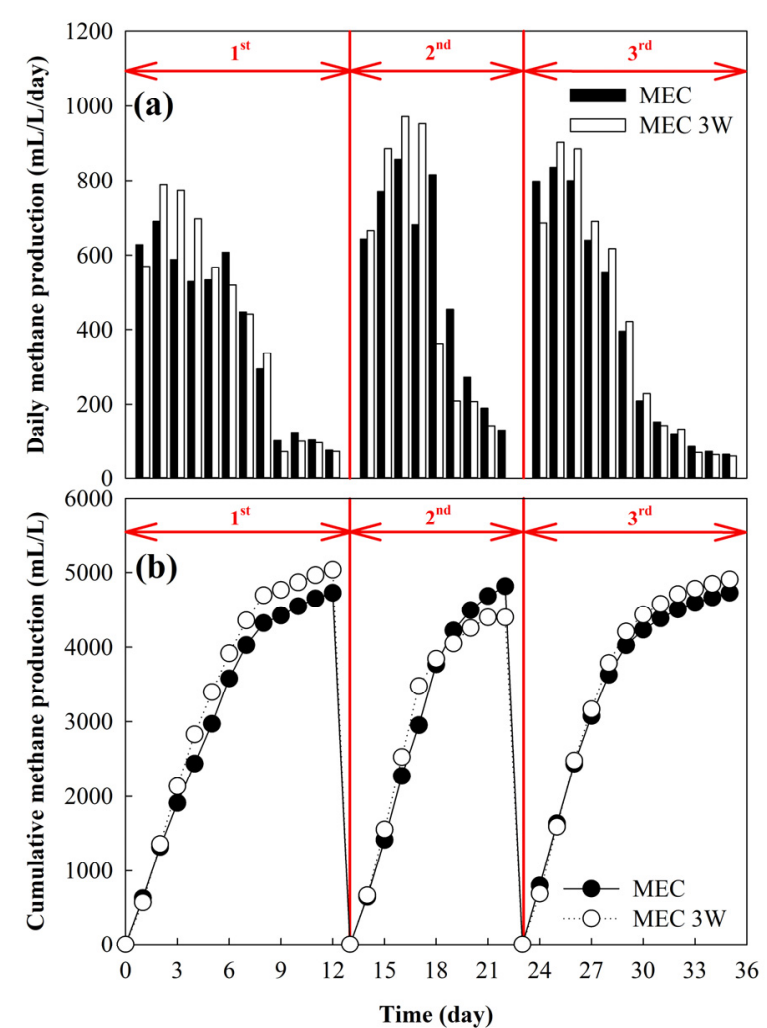

Fig. 3. Daily methane production (a) and cumulative methane production (b) of MECs.

발생되는 $\mathrm{OH} \cdot, \mathrm{HO}_{2} \cdot, \mathrm{H} \cdot$ 라디칼이 하수슬러지 내의 슬러지 플록을 파괴시키고, 고형물이 액상 형태로 분해되며 유화되어 섞이며 메탄 생성균이 최종적으로 소모하기 용이한 형태가 되었고, 따라서 제거될 수 있는 유기물의 양이 증가되었기 때 문으로 사료된다. ${ }^{33)}$ 메탄 수율은 유기물 제거율과 비슷한 경 향을 보여주었다(Fig. 4). MEC $3 \mathrm{~W}$ 는 $377.4 \mathrm{~mL} / \mathrm{g} \mathrm{VS}_{\text {in }}$ 으로 $\mathrm{MEC}$ 에 비해 $0.4 \%$ 증가한 경향을 보여주었다. 기존 연구에서 도 음식물 쓰레기와 계분을 병합소화 하였을 때 $130 \mathrm{~W}$ 로 30 분간 초음파 전처리 시 $11.3 \%$ 의 메탄 수율이 상승하는 결 과를 보여주었다. ${ }^{34)} \mathrm{WAS}$ 를 $\mathrm{BMP}$ 실험을 통해 운전성능을 평 가하였을 때 $35,000 \mathrm{~kJ} / \mathrm{kg}$ TS의 에너지를 주사하여 초음파 전처리를 수행하였을 때 $31.4 \%$ 의 메탄 수율 향상을 보여주었 다. MEC $3 \mathrm{~W}$ 의 메탄 수율이 더 높았던 이유는 초음파 전처리의 미세공동 현상으로 인한 세포벽 파괴와 세포 붕괴를 통해 내부에 있던 용존 물질들이 방출되며 가수분해가 강제되어 세포외전자 방출균(Exoelectrogen)과 메탄 생산균이 소모하기 더 용이한 형태로 바꾸었기 때문으로 판단된다. ${ }^{28)}$

\section{4. 결 론}

본 연구에서는 미생물전기분해전지(MEC)를 이용하여 초음 파 전처리가 적용된 생슬러지를 기질로 운전하였을 때 성능을 평가하였다. 메탄 생산에서 생슬러지에 $3 \mathrm{~W} / \mathrm{mL}$ energy density

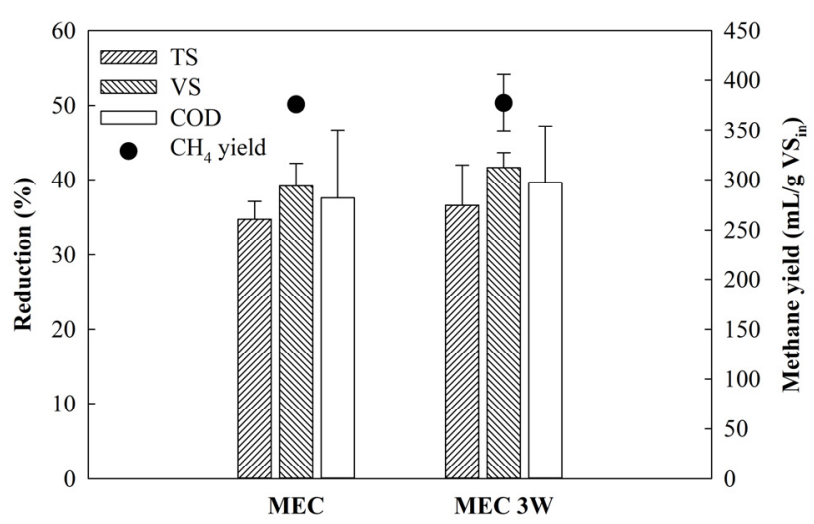

Fig.4. Organic matter removal and methane yield of MECs.

로 초음파 전처리를 수행했던 MEC $3 \mathrm{~W}$ 의 메탄 생산량은 평 균 4,970 mL/day로 전처리를 수행하지 않은 $\mathrm{MEC}$ 에 비해 243 $\mathrm{mL} / \mathrm{L}$ 높았다. Modified Gompertz analysis에서 $R_{m}$ 은 MEC $3 \mathrm{~W}$ 가 $938.5 \mathrm{~mL} / \mathrm{L} / \mathrm{day}$ 로 더 높았으나 $\lambda$ 는 0.46 일로 $\mathrm{MEC}$ 에 비해 0.12 일 길었다. 유기물 제거에서 MEC $3 \mathrm{~W}$ 는 TS는 $1.8 \%$, $\mathrm{VS}$ 는 $2.4 \%, \mathrm{COD}$ 는 $2.0 \%$ 높았다. 메탄 수율에 있어 $\mathrm{MEC} 3 \mathrm{~W}$ 가 $377.4 \mathrm{~mL} / \mathrm{g} \mathrm{VS}_{\mathrm{in}}$ 으로 $\mathrm{MEC}$ 에 비해 $0.4 \%$ 높은 경향을 보여 주었다. 추후 전처리가 적용된 하수 슬러지를 기질로 하여 최 적의 운전성능을 보여주기 위한 가용화도 최적화와 전처리 방법을 찾는 후속 연구가 필요하다.

\section{Acknowledgement}

본 논문은 2020년도 경상국립대학교 대학회계 연구비로 지 원된 연구입니다.

\section{References}

1. Ministry of Environment, The sewerage statistics, Republic of Korea(2008-2018).

2. International Maritime Organization, Convention on the prevention of marine pollution by dumping of wastes and other matter, London convention and protocol(1996).

3. D. P. Van, T. Fujiwara, B. L. Tho, P. P. S. Toan, G. H. Minh, A review of anaerobic digestion systems for biodegradable waste: configurations, operating parameters, and current trends, Envirion. Eng. Res., 25(1), 1-17(2020).

4. G. Náthia-Neves, M. Berni, G. Dragone, S. I. Mussatto, T. Forster-Carneiro, Anaerobic digestion process: technological aspects and recent developments, Int. J. Environ. Sci. Technol., 15, 2033-2046(2018).

5. Q. Yin, X. Zhu, G. Zhan, T. Bo, Y. Yang, Y. Tao, X. He, D. Li, Z. Yan, Enhanced methane production in an anaerobic digestion and microbial electrolysis cell coupled system with co-cultivation of Geobacter and Methanosarcina, J. Environ. Sci., 42, 210-214(2015).

6. Q. Feng, Y-C. Song, B-U. Bae, Influence of applied voltage 
on the performance of bioelectrochemical anaerobic digestion of sewage sludge and planktonic microbial communities at ambient temperature, Bioresour. Technol., 220, 500-508(2016).

7. Y-C. Song, Q. Feng, Y. Ahn, Performance of the Bioelectrochemical Anaerobic Digestion of Sewage Sludge at Different Hydraulic Retention Times, Energy Fuels, 30(1), 352-359(2016).

8. A. A. Pawar, A. Karthic, S. Lee, S. Pandit, S. P. Jung, Microbial electrolysis cells for electromethanogenesis: materials, configurations and operations, Environ. Eng. Res., 27(1), 200484(2022).

9. Y. Feng, Y. Zhang, S. Chen, X. Quan, Enhanced production of methane from waste activated sludge by the combination of high-solid anaerobic digestion and microbial electrolysis cell with iron-graphite electrode, Chem. Eng. J., 259, 787-794(2015).

10. Z. Zhao, Y. Zhang, X. Quan, H. Zhao, Evaluation on direct interspecies electron transfer in anaerobic sludge digestion of microbial electrolysis cell, Bioresour. Technol., 200, 235-244(2016).

11. K. Hu, L. Xu, W. Chen, S. Jia, W. Wang, F. Han, Degradation of organics extracted from dewatered sludge by alkaline pretreatment in microbial electrolysis cell, Environ. Sci. Pollut. Res., 25(9), 8715-8724(2018).

12. X. Liu, Q. Xu, D. Wang, J. Zhao, Y. Wu, Y. Liu, B-J. Ni, Q. Wang, G. Zeng, X. Li, Q. Yang, Improved methane production from waste activated sludge by combining free ammonia with heat pretreatment: performance, mechanisms and applications, Bioresour. Technol., 268, 230-236(2018).

13. A. Gonzalez, A. T. W. M. Hendriks, J. B. van Lier, M. de Kreuk, Pre-treatments to enhance the biodegradability of waste activated sludge: elucidating the rate limiting step, Biotechnol. Adv., 36(5), 1434-1469(2018).

14. J. Ariunbaatar, A. Panico, G. Esposito, F. Pirozzi, P. N. L. Lens, Pretreatment methods to enhance anaerobic digestion of organic solid waste, Appl. Energy, 123, 143-156(2014).

15. S. Pilli, P. Bhunia, S. Yan, R. J. LeBlanc, R. D. Tyagi, R. Y. Surampalli, Ultrasonic pretreatment of sludge: a review, Ultrason Sonochem, 18(1), 1-18(2011).

16. M. Á. Martín, I. González, A. Serrano, J. Á. Siles, Evaluation of the improvement of sonication pre-treatment in the anaerobic digestion of sewage sludge, J. Environ. Manage., 147, 330-337(2015).

17. H. Bao, H. Yang, H. Zhang, Y. Liu, H. Su, M. Shen, Improving methane productivity of waste activated sludge by ultrasound and alkali pretreatment in microbial electrolysis cell and anaerobic digestion coupled system, Environ. Res., 108863 (2019).

18. S. Im, Y. Ahn, J-W. Chung, Influence of electrode spacing on methane production in microbial electrolysis cell fed with sewage sludge, J. Korean Soc. Environ. Eng., 37(12), 682-688 (2015).

19. D-H. Kim, E. Jeong, S-E. Oh, H-S. Shin, Combined (alkaline+ultrasonic) pretreatment effect on sewage sludge disintegration, Water Res., 44(10), 3093-3100(2010).
20. Y. Ahn, S. Im, J-W. Chung, Optimizing the operating temperature for microbial electrolysis cell treating sewage sludge, Int. J. Hydrog., 42(45), 27784-27791(2017).

21. R. Baird, L. Bridgewater, Standard Methods for the Examination of Water and Wastewater, 23 ${ }^{\text {rd }}$, American Public Health Association (AHPA), Washington, D.C., USA (2018).

22. Z. M. A. Bundhoo, Effects of microwave and ultrasound irradiations on dark fermentative bio-hydrogen production from food and yard wastes, Int. J. Hydrog, 42(7), 4040-4050 (2017).

23. G. Xu, S. Chen, J. Shi, S. Wang, G. Zhu, Combination treatment of ultrasound and ozone for improving solubilization and anaerobic biodegradability of waste activated sludge, J. Hazard. Mater., 180(1-3), 340-346(2010).

24. K. Hu, W. Chen, S. Jia, W. Wang, F. Han, Enhanced Degradation of Waste Activated Sludge in Microbial Electrolysis Cell by Ultrasonic Treatment, Front. microbiol., 10, 128(2019).

25. S. Pérez-Elvira, M. Fdz-Polanco, F. I. Plaza, G. Garralón, F. Fdz-Polanco, Ultrasound pre-treatment for anaerobic digestion improvement, Water Sci. Technol., 60(6), 1525-1532(2009).

26. A. C. Lizama, C. C. Figueiras, R. R. Herrera, A. Z. Pedreguera, J. E. Ruiz Espinoza, Effects of ultrasonic pretreatment on the solubilization and kinetic study of biogas production from anaerobic digestion of waste activated sludge, Int. Biodeterior, 123, 1-9(2017).

27. D. Elalami, H. Carrere, K. Abdelouahdi, D. Garcia-Bernet, J. Peydecastaing, G. Vaca-Medina, D. Oukarroum, Y. Zeroual, A. Barakat, Mild microwaves, ultrasonic and alkaline pretreatments for improving methane production: impact on biochemical and structural properties of olive pomace, Bioresour. Technol., 122591(2019).

28. E. Elbeshbishy, H. Hafez, B. R. Dhar, G. Nakhla, Single and combined effect of various pretreatment methods for biohydrogen production from food waste, Int. J. Hydrog, 36(17), 11379-11387(2011).

29. C. M. Braguglia, M. C. Gagliano, S. Rossetti, High frequency ultrasound pretreatment for sludge anaerobic digestion: effect on floc structure and microbial population, Bioresour. Technol., 110, 43-49(2012).

30. J. Park, B. Lee, D. Tian, H. Jun, Bioelectrochemical enhancement of methane production from highly concentrated food waste in a combined anaerobic digester and microbial electrolysis cell, Bioresour. Technol., 247, 226-233(2018).

31. X. Li, S. Guo, Y. Peng, Y. He, S. Wang, L. Li, M. Zhao, Anaerobic digestion using ultrasound as pretreatment approach: changes in waste activated sludge, anaerobic digestion performances and digestive microbial populations, Biochem. Eng. J., 139, 139-145(2018).

32. M. A. Cella, D. Akgul, C. Eskicioglu, Assessment of microbial viability in municipal sludge following ultrasound and microwave pretreatments and resulting impacts on the efficiency of anaerobic sludge digestion, Appl. Microbiol. Biotechnol., 100(6), 2855-286(2015). 
33. L. Yue, J. Cheng, S. Tang, X. An, J. Hua, H. Dong, J. Zhou, Ultrasound and microwave pretreatments promote methane production potential and energy conversion during anaerobic digestion of lipid and food wastes, Energy, 228, 120525(2021).

34. B. Deepanraj, V. Sivasubramanian, S. Jayaraj, Effect of substrate pretreatment on biogas production through anaerobic digestion of food waste, Int. J. Hydrog., 42(42), 26522-26528(2017).

\section{Declaration of Competing Interest}

The authors declare that they have no known competing financial interests or personal relationships that could have appeared to influence the work reported in this paper.

\section{Authors and Contribution Statement}

\section{Donghwan Lee}

Department of Energy Engineering, Gyeongsang National University, Undergraduate, ORCID (1) 0000-0002-8488-7387: Data curation, Visualization, Writing - original draft

\section{Jinwon Kim}

Department of Energy Engineering, Gyeongsang National University, Undergraduate, ORCID (1) 0000-0002-5462-1561: Data curation, Visualization, Writing - original draft

\section{Hwijin Seo}

Department of Energy Engineering, Gyeongsang National University, Ph.D. Student, ORCiD () 0000-0002-8944-1018: Conceptualization, Methodology, Visualization, Data analysis, Writing - original draft

\section{Yongtae Ahn}

Department of Energy Engineering, Future Convergence Technology Research Institute, Gyeongsang National University, Associate Professor, ORCID @ 0000-0001-6294-710X: Supervision, Conceptualization, Funding acquisition, Resources, Writing review and editing 